$1-1-1980$

\title{
Effect of improvement cuttings and thinnings on the understories of mixed oak and cove hardwood stands
}

Kenneth B. Kirkham

Kenneth L. Carvell

Follow this and additional works at: https://researchrepository.wvu.edu/ wv_agricultural_and_forestry_experiment_station_bulletins

\section{Digital Commons Citation}

Kirkham, Kenneth B. and Carvell, Kenneth L., "Effect of improvement cuttings and thinnings on the understories of mixed oak and cove hardwood stands" (1980). West Virginia Agricultural and Forestry Experiment Station Bulletins. 673.

https://researchrepository.wvu.edu/wv_agricultural_and_forestry_experiment_station_bulletins/570 
Effect of Improvement Cuttings and Thinnings on the Understories of Mixed Oak and Cove Hardwood Stands d [ JUN 27 1980

West Virginia University WEST VIRGINIA UNIVERSITY Agricultural and Forestry Experiment Station

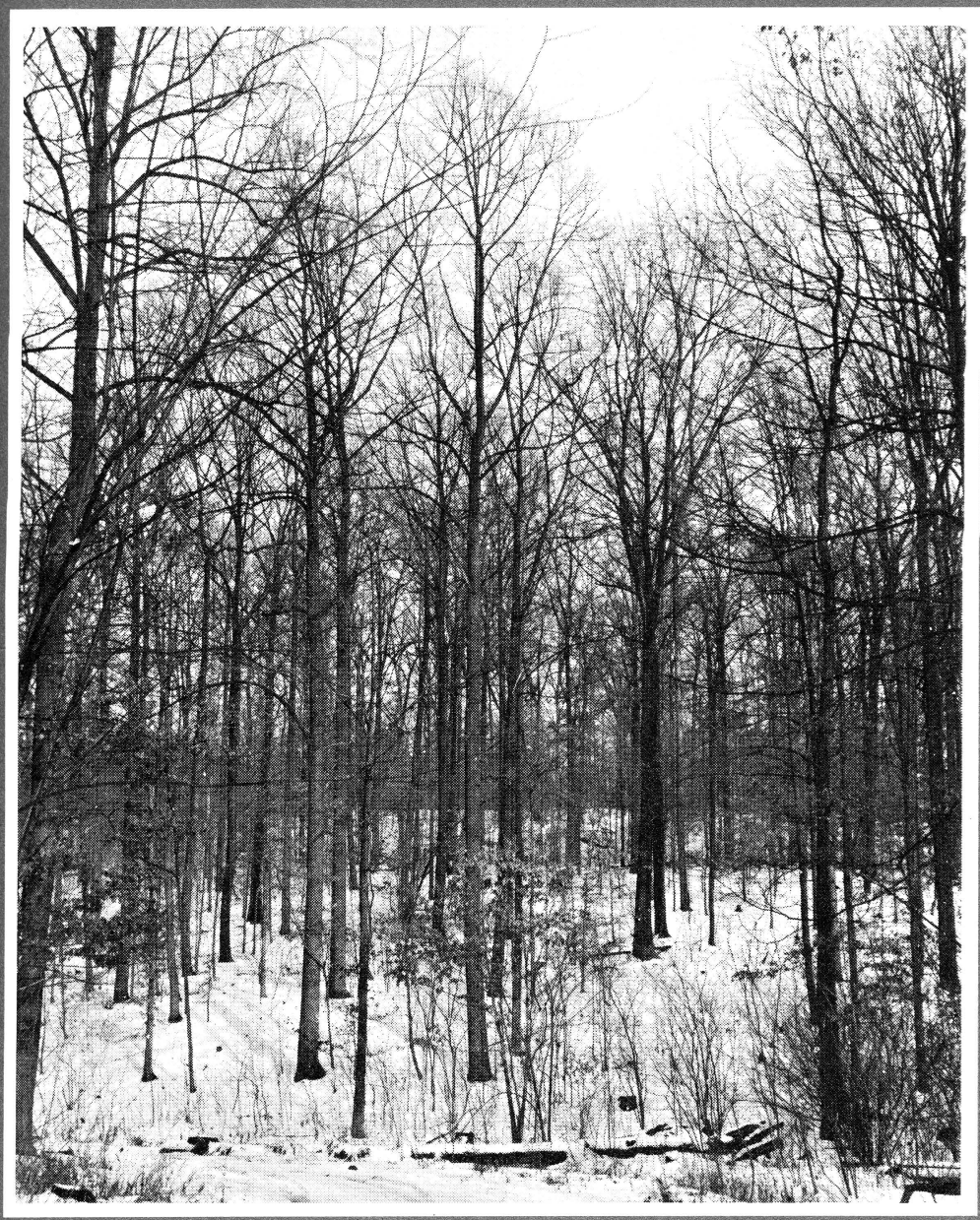




\section{Authors}

Kenneth B. Kirkham is a former Research Assistant, and Kenneth L. Carvell is Professor of Forest Ecology at the West Virginia University Division of Forestry and West Virginia Agricultural and Forestry Experiment Station. Kirkham is presently employed by WESTVACO, Covington, Va.

West Virginia University Agricultural and Forestry Experiment Station

College of Agriculture and Forestry

Dale W. Zinn, Director

Morgantown 


\title{
Effect of Improvement Cuttings and Thinnings on the Understories of Mixed Oak and Cove Hardwood Stands
}

\author{
Kenneth B. Kirkham and Kenneth L. Carvell
}

\section{Introduction}

Forest managers have long been aware of the significance of stand understories in the formation of the succeeding stand (Leffelman and Hawley, 1925; Clark and Watt, 1971; Sanders, 1972). More recently it has also become apparent that understory shrubs and trees, and possibly herbaceous plants, compete with overstory trees for moisture and nutrients (Zahner, 1958; Bower and Ferguson, 1968; Grano, 1970). Wildlife biologists are giving increased attention to understory characteristics since this layer provides cover and food for many wildlife species (Sharp, 1957; Bennett, 1962; Krefting, 1962; Knierim et al., 1971). Today information on understory development is also of interest from an esthetic and recreational standpoint since undergrowth can either decrease or enhance the value of forest areas for these uses.

Large acreages in the eastern United States presently support second- and third-growth even-aged hardwood stands. Silvicultural treatments often needed in pole-size hardwoods are improvement cuttings or thinnings. Thus it is important to know more about the effects of intermediate cuttings on biomass and number of understory species.

\section{Location and Description of Study Area}

The study area is located on the unglaciated Aliegheny Plateau in northcentral West Virginia. The virgin mixed oak and cove hardwood forests were cut in the early 1800's for charcoal wood. The most recent logging took place between 1912-1928. After these cuttings, wildfire burned over this tract frequently until 1936 when the land was acquired for the Coopers Rock State Forest. Since then no wildfire has occurred, thus most of the present stands originated from sprouts after the last fires in the early and mid-thirties.

Each summer between 1949 and 1953 one block of eight 0.20 ha (1/2-acre) plots was established on the West Virginia University Forest, a part of the Coopers Rock State Forest. Three blocks were located in mixed oak and two in cove hardwood types. Stands were 13-17 years old at time of plot establishment. At that time, four of the eight plots in each block received an improvement cutting in which unmerchantable residual trees, undesirable species, and trees of poor form were removed. 
During the next 25 years an improved plot and an unimproved plot in each block received one of the following thinning treatments: low thinning, high thinning, selection thinning, or no thinning. In low thinning, all merchantable lower-crown-class trees and weak codominants were cut. High thinning removed those upper-crown-class trees that interfered with the development of the most promising trees. In selection thinning, dominant trees were removed if they had large crowns and poor natural pruning. In all cuttings other merchantable stems were removed if it were determined they would not live until the next cutting. On plots that had no initial improvement cut, old residual trees were girdled or harvested at the time of the first thinning, five years after plot establishment.

Tree diameters, heights, and volumes on each plot were re-measured at fiveyear intervals, but thinning occurred only when a merchantable volume could be obtained, which for most plots resulted in a ten-year thinning cycle.

\section{Data Collection}

Understory data were gathered during June-August, 1978. On each plot eight milacre subplots were randomly located, two in each of four quadrants. Woody and herbaceous vegetation rooted within the subplots was tallied by species and height (10-cm height classes). All herbaceous plots and all woody plants less than $3 \mathrm{~cm}$ diameter at base were clipped at ground level and counted. Cut vegetation was segregated into greenbrier, herbaceous, and woody species, dried for 24 hours in a forced air oven, and weighed to the nearest $0.01 \mathrm{gm}$.

\section{Methodology}

Quantitative Data. The data for each of the eight plots in each block, by cover type, were totaled. Dry weight above ground was recorded for greenbrier, herbaceous, and woody plants. The numbers of herbaceous and woody species were also recorded (Table 1 ).

Number of woody stems is an average of the number of woody stems on each milacre subplot. Average height of woody stems is an average of the mean height of each subplot. Since the abundance of very small seedlings (less than $2 \mathrm{dm}$ ) on some plots could disproportionately affect both number of woody stems and average woody height, values for the number of woody stems greater than $2 \mathrm{dm}$ and average height of woody stems greater than $2 \mathrm{dm}$ were included.

Site index values were determined using the average total height in meters for dominant and codominant oaks. Wiant's (1975) formulation of Schnur's curves was applied using a base age of 50 .

Basal area values in square meters per hectare are expressions of the average basal area of the plots between the period of plot establishment and 1978. These reflected the lower basal areas for thinned plots when compared to the controls (Charlton et al., 1980).

In the analysis, site index and basal area values were treated as covariates to increase the precision with which treatment effects on dependent variables could be measured (Steel and Torrie, 1960). This was accomplished by adjusting dependent variables by regression so they would be estimates of 


\section{Table 1}

Mixed oak and cove type parameters. Figures are averages by type of the subplot data irrespective of the cutting treatment of the plots. Weight and number of species are thus given per milacre.

\begin{tabular}{lcc}
\hline \hline Variable & Oak & Cove \\
\hline Site Index & $22.19 \mathrm{~m}$ & $25.85 \mathrm{~m}$ \\
& $72.8 \mathrm{ft}$ & $84.8 \mathrm{ft}$ \\
Basal Area & $19.56 \mathrm{~m}^{2} / \mathrm{ha}$ & $24.22 \mathrm{~m}^{2} / \mathrm{ha}$ \\
& $85.20 \mathrm{ft}^{2} / \mathrm{ac}$ & $105.50 \mathrm{ft}^{2} / \mathrm{ac}$ \\
Herbaceous Weight & $107.2 \mathrm{~g}$ & $649.4 \mathrm{~g}$ \\
Greenbrier Weight & $610.7 \mathrm{~g}$ & $202.4 \mathrm{~g}$ \\
Woody Weight & $2,327.0 \mathrm{~g}$ & $2,164.9 \mathrm{~g}$ \\
Total Weight & $3,044.9 \mathrm{~g}$ & $3,016.7 \mathrm{~g}$ \\
\# Herbaceous Species & 10.6 & 26.9 \\
\#Woody Species & 12.6 & 11.2 \\
Total \# Species & 23.2 & 38.1 \\
\# Woody Species/ & & \\
\# Herbaceous Species & 1.18 & 0.416 \\
; Woody Stems & 46.2 & 30.0 \\
\# Woody Stems 2dm + & 15.9 & 12.3 \\
\# Average Woody Height & & $3.24 \mathrm{dm}$ \\
(All Stems) & $2.40 \mathrm{dm}$ & $5.40 \mathrm{dm}$ \\
Average Woody & & \\
Height 2dm + & $4.40 \mathrm{dm}$ & \\
\hline
\end{tabular}

what they would have been had site index and basal area of each plot been the same.

Tables 2 and 3 report mixed oak and cove means by improvement, thinning, and improvement-thinning combinations. Pair-wise comparisons were made between values within a treatment category. In these tables, means which do not differ significantly have the same adjacent alphabetical letters. Lower case letters indicate that significant differences were found in the analysis if no covariate was included. Upper-case letters to the right correspond to significance found by the analysis with site index and basal area included as covariates.

Qualitative Data. The "importance value" developed by Curtis and McIntosh (1951) was used to synthesize the data. This index is useful where plant communities are highly heterogeneous and community classification based on dominants or codominants becomes impractical. This value is based on the premise that most species do not normally reach a high level of importance in the community, but those that do serve as an index (Smith, 1974). 
Table 2

Mixed oak means by improvement, thinning, and improvement-thinning combinations.

\begin{tabular}{|c|c|c|c|c|c|c|c|c|c|}
\hline Treatment & $\begin{array}{l}\text { Herbaceous } \\
\text { Weight } \\
\text { (g) }\end{array}$ & $\begin{array}{c}\text { Greenbrier } \\
\text { Weight } \\
\text { (g) }\end{array}$ & $\begin{array}{l}\text { Woody } \\
\text { Weight } \\
\text { (g) }\end{array}$ & $\begin{array}{l}\text { Total } \\
\text { Weight } \\
\text { (g) }\end{array}$ & $\begin{array}{l}\text { Number of } \\
\text { Herbaceous } \\
\text { Species }\end{array}$ & $\begin{array}{l}\text { Number } \\
\text { of Woody } \\
\text { Species }\end{array}$ & $\begin{array}{l}\text { Number } \\
\text { Of Woody } \\
\text { Stems }^{1}\end{array}$ & $\begin{array}{c}\text { Average } \\
\text { Woody Ht. } \\
\text { Height } \\
(\mathrm{dm})\end{array}$ & $\begin{array}{c}\text { Average } \\
\text { Woody Ht. } \\
2 \mathrm{dm}+ \\
(\mathrm{dm}) \\
\end{array}$ \\
\hline \multicolumn{10}{|l|}{ Improvement } \\
\hline O (None) & 108.9 & 539.6 & 2573 & 3221 & 10.3 & 12.0 & $47.2-17.3$ & 2.58 & $4.14 \mathrm{~A}$ \\
\hline I (Improvement) & 106.5 & 681.8 & 2081 & 2869 & 10.8 & 13.2 & $45.1-14.4$ & 2.23 & $4.07 \mathrm{~B}$ \\
\hline OT (None) & 95.6 & $488.0 \mathrm{AB}^{2}$ & a $1356 \mathrm{~A}$ & $1940 \mathrm{AB}$ & a $10.5 \mathrm{~A}$ & 12.0 & $48.6-16.4$ & $2.18 \mathrm{~A}$ & $3.57 \mathrm{~A}$ \\
\hline LT (Low) & 125.6 & 514.3 B & $a b 2237$ A & ab $2876 \mathrm{ABC}$ & a $10.0 \mathrm{AB}$ & 12.7 & $46.1-12.9$ & $2.12 \mathrm{~A}$ & $4.04 \mathrm{~A} \mathrm{C}$ \\
\hline HT (High) & 97.8 & $898.1 \mathrm{~A}$ & b3208 B & c 4204 & $13.7 \mathrm{~B}$ & 12.5 & $42.1-16.3$ & $2.82 B$ & c5.32 B \\
\hline ST (Selection) & 110.0 & $542.4 \mathrm{AB}$ & $a b 2507 \mathrm{AB}$ & bc 3159 A C & a $8.2 \mathrm{~A}$ & 13.2 & $47.8-18.0$ & $2.50 \mathrm{AB}$ & bc $4.69 \mathrm{BC}$ \\
\hline \multicolumn{10}{|l|}{$\begin{array}{l}\text { Improvement- } \\
\text { Thinning }\end{array}$} \\
\hline O-OT & 161.8 & 274.9 & 1417 & 1854 & 11.3 & 11.7 & $53.6-20.6$ & 2.44 & 3.81 \\
\hline $\mathrm{O}-\mathrm{HT}$ & 36.6 & 1035.4 & * 4407 & * 5479 & 10.0 & 10.7 & $33.9-14.3$ & 3.34 & * 6.34 \\
\hline O-ST & 76.6 & 292.2 & 2296 & 2665 & 7.0 & 13.3 & $54.3-21.3$ & *2.19 & 4.50 \\
\hline I-OT & 29.4 & 701.0 & 1294 & 2025 & 9.6 & 12.3 & $43.6-12.3$ & 1.91 & 3.34 \\
\hline I-LT & 94.1 & 472.6 & 2302 & 2869 & 7.0 & 13.0 & $45.2-12.7$ & 1.90 & 3.75 \\
\hline $\mathrm{I}-\mathrm{HT}$ & 159.0 & 760.8 & 2010 & 2930 & * 17.3 & 14.3 & $50.3-18.2$ & 2.29 & 4.29 \\
\hline $\mathrm{I}-\mathrm{ST}$ & 143.4 & 792.6 & 2718 & 3654 & 9.3 & 13.0 & $41.3-14.6$ & 2.82 & 4.88 \\
\hline Average & 107.2 & 610.7 & 2327.0 & 3044.9 & 10.6 & 12.6 & $46.1-15.9$ & 2.40 & 4.40 \\
\hline
\end{tabular}

'The first figure is the total number of woody stems, and the second is the total number of woody stems over $2 \mathrm{dm}$ in height.

'The firt fhat do not differ significantly by pair-wise comparisons at the 11 percent level have the same alphabetical letter adjacent to them. Lower-ease letters "Means correspond to non-covariate analysis. Upper-case letters represent analysis with site index and basal area as covariates.

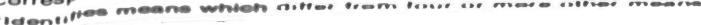


Table 3

Cove hardwood means by improvement, thinning, and improvement-thinning combinations.

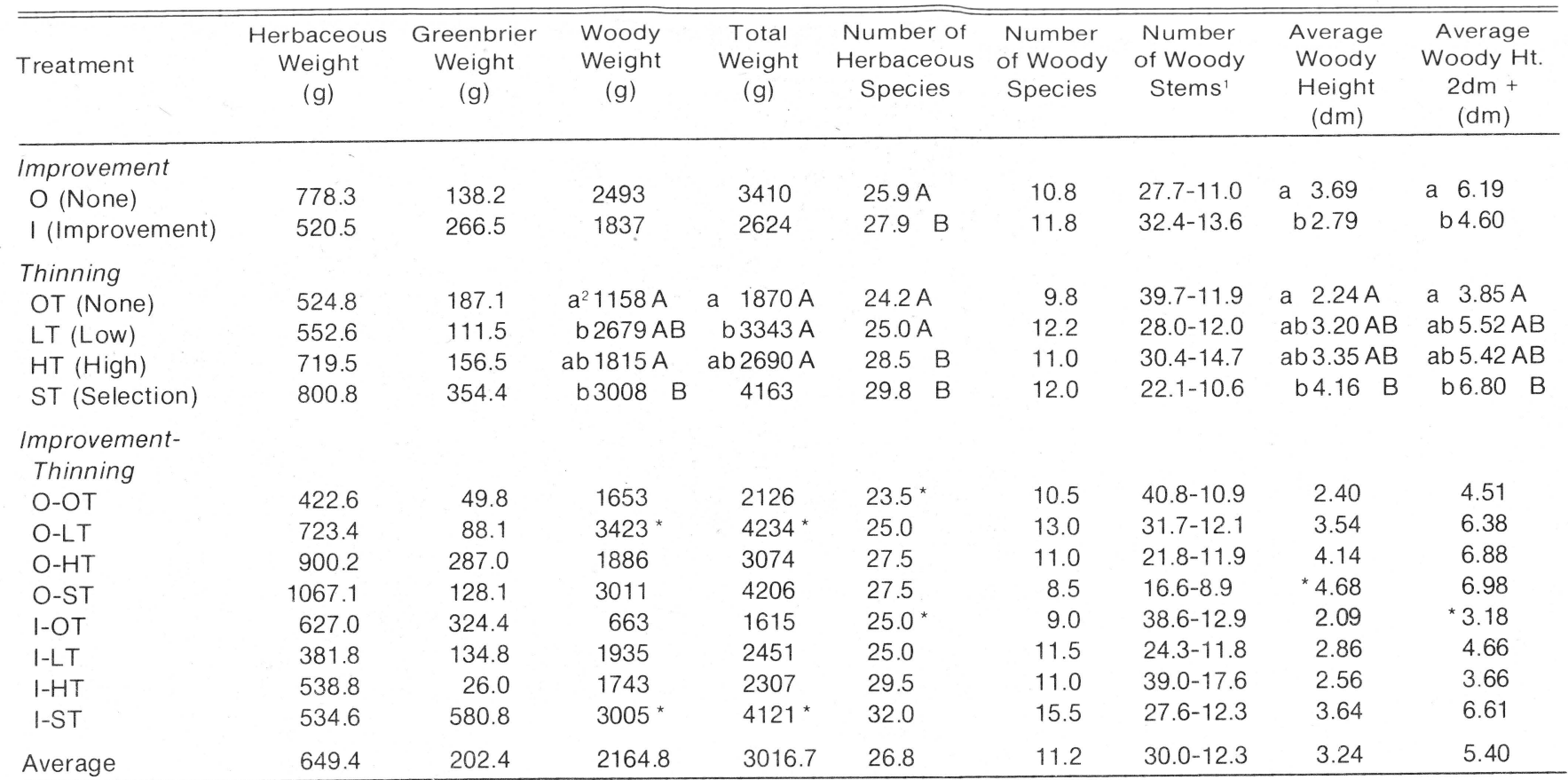

'The first figure is the total number of woody stems, and the second is the total number of woody stems over $2 \mathrm{dm}$ in height.

${ }^{2}$ Means that do not differ significantly by pair-wise comparisons at the 11 percent level have the same alphabetical letter adjacent to them. Lower-case letters correspond to non-covariate analysis. Upper-case letters represent analysis with site index and basal area as covariates.

${ }^{\star}$ Identifies means which differ from four or more other means. 
The importance value for any given species is calculated as the sum of its relative frequency, relative density, and relative dominance where:

$$
\begin{aligned}
\text { frequency } & =\frac{\text { number of plots where species A occurs }}{\text { total number of plots }} \times 100 \\
\begin{aligned}
\text { relative } \\
\text { frequency }
\end{aligned} & =\frac{\text { frequency value for species } A}{\text { total frequency value for all species }} \times 100 \\
\text { relative } & =\frac{\text { individuals of species } A}{\text { total individuals of all species }} \times 100 \\
\text { density } & \text { relative } \\
\text { dominance } & =\frac{\text { total cover species A exerts }}{\text { total cover of all species }} \times 100
\end{aligned}
$$

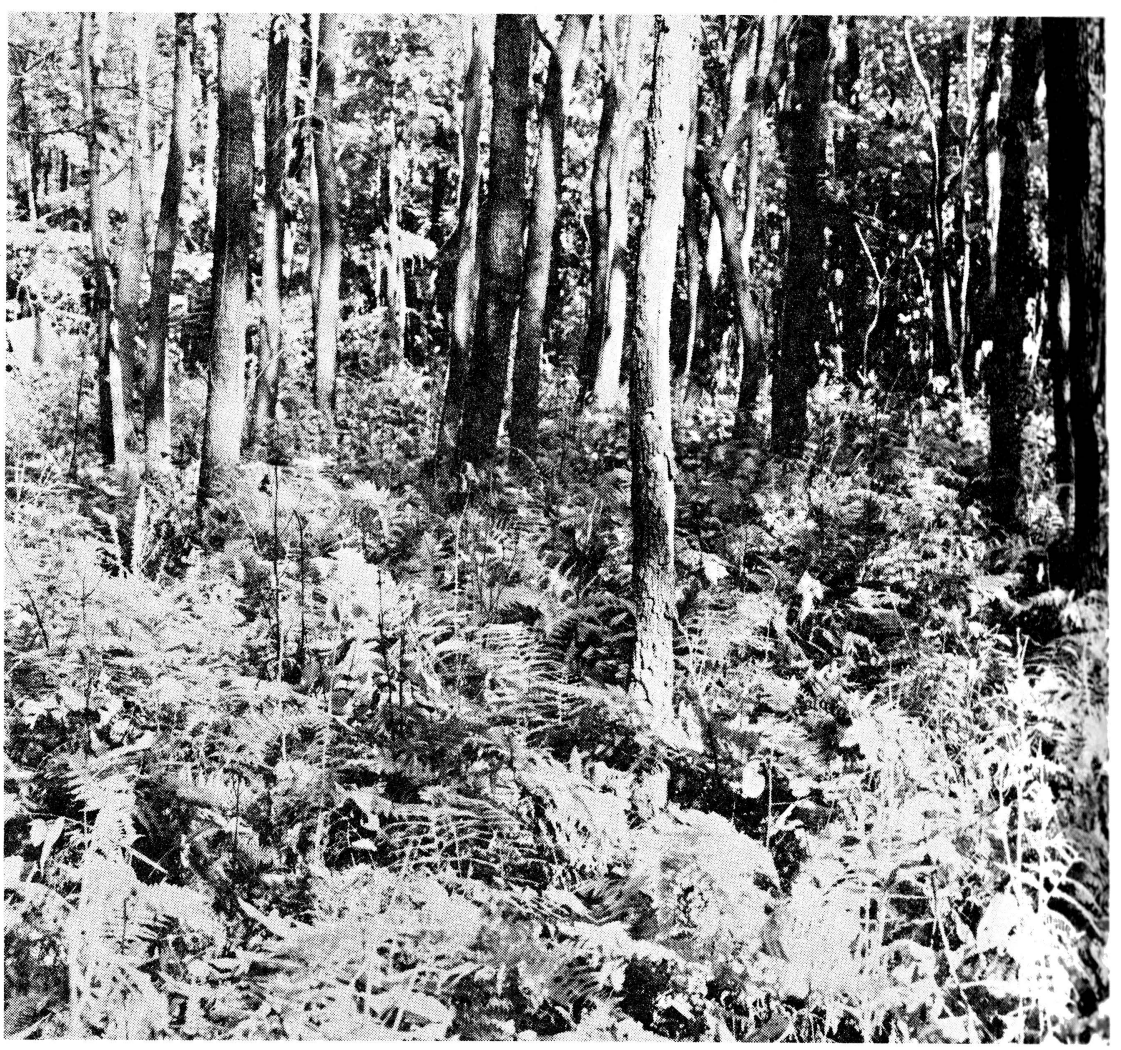

On cove hardwood sites, thinnings that open the main crown canopy result in an understory of many herbaceous species, including a large number of ferns They also bring in some woody shrubs and tree seedlings. 


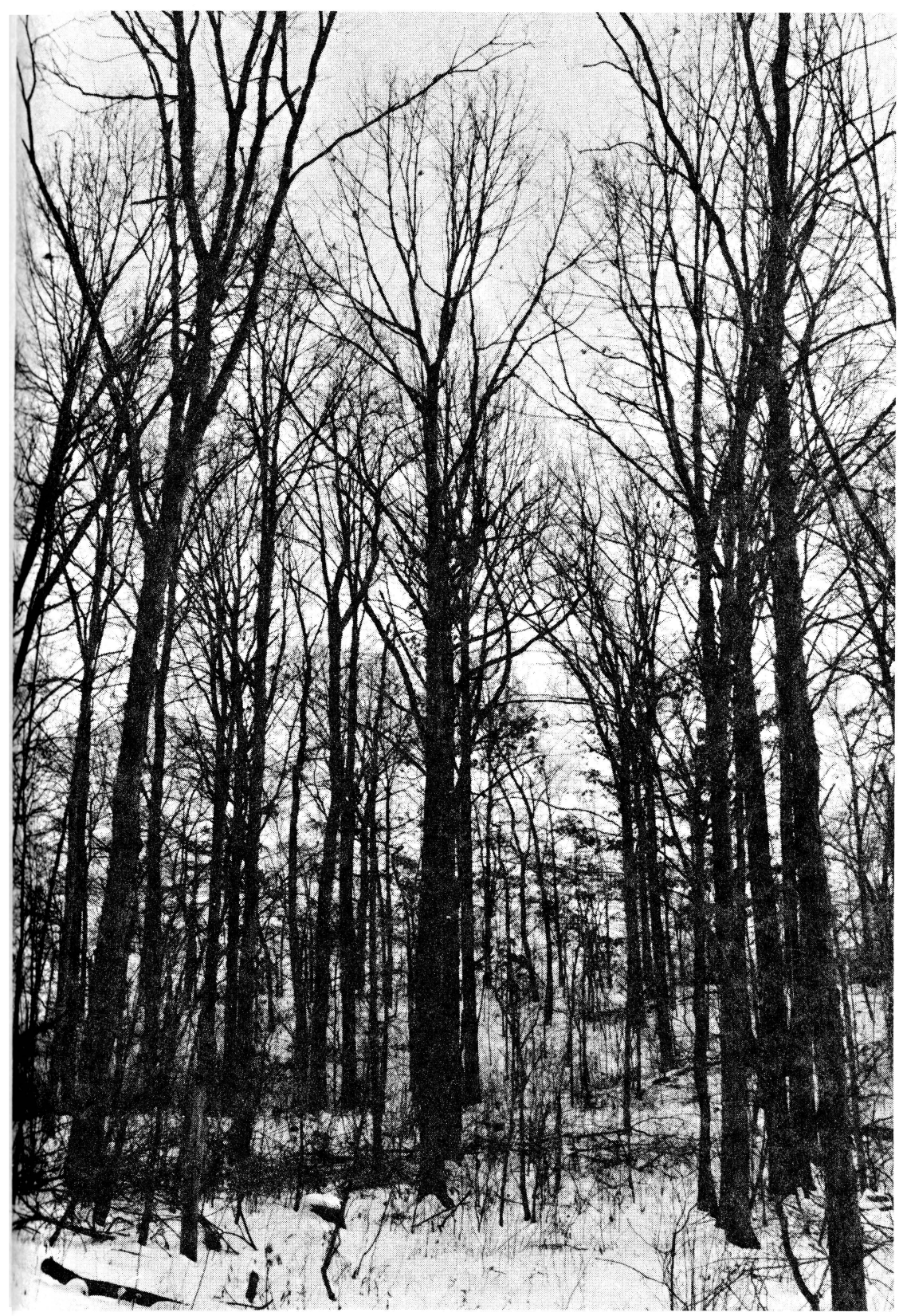

Overstocked, dense hardwood stands generally have little understory development. Thinnings which create openings in the crown canopy quickly establish a dense understory of both herbaceous and woody plants. 
The summation of relative frequency, relative density, and relative cover values produces an importance value which ranges from 0-300 for each species and sums 300 for each species group. In this manner a species is assigned an index by considering its participation in the community based on a combined measure of its frequency, density, and cover relative to other species in the community.

Understory vegetation data gathered on the study plots was separated for analysis by forest type and thinning treatment for woody and herbaceous plants. Overall importance values were determined irrespective of the intermediate cuttings that plots received to illustrate the general hierarchy of species' importance within a group. These importance values are presented in Tables 4 through 7.

\section{Table 4}

Treatment and overall importance values of herbaceous species on mixed oak sites.

\begin{tabular}{lrrrrr}
\hline \hline & \multicolumn{5}{c}{ Treatment* } \\
Species & OT & \multicolumn{1}{c}{ LT } & \multicolumn{1}{c}{ HT } & \multicolumn{1}{c}{ ST } & Overall \\
\hline Common greenbrier & 85.99 & 80.60 & 90.88 & 93.88 & 87.56 \\
Hay-scented fern & 80.54 & 64.02 & 25.87 & 58.46 & 55.72 \\
Whorled loosestrife & 18.35 & 30.96 & 19.66 & 40.15 & 26.09 \\
Saw brier & 12.92 & 26.82 & 11.38 & 30.83 & 19.49 \\
Rubus spp. & 1.54 & 31.11 & 18.91 & 15.67 & 17.17 \\
Wild yam & 12.52 & 12.01 & 13.23 & 13.18 & 12.67 \\
Indian cucumber-root & 20.68 & 6.61 & 9.46 & 10.98 & 11.90 \\
Blue wood aster & 3.11 & 7.33 & 12.55 & 4.13 & 7.31 \\
Wreath goldenrod & 8.57 & 3.57 & 7.45 & 2.22 & 5.66 \\
Grass spp. & 7.19 & 2.61 & 6.05 & 7.85 & 5.57 \\
Wild sarsaparilla & 8.64 & 2.42 & 5.74 & 4.02 & 5.24 \\
New York fern & 0.00 & 0.00 & 16.27 & 0.00 & 4.90 \\
Indian pipe & 4.63 & 6.42 & 3.96 & 1.76 & 4.32 \\
Common blue violet & 3.14 & 0.77 & 10.69 & 0.00 & 4.30 \\
Common Solomon's seal & 5.14 & 4.14 & 4.14 & 3.44 & 4.22 \\
Sessile-leaved bellwort & 4.33 & 4.04 & 4.66 & 3.96 & 3.39 \\
Annual bluegrass & 1.02 & 0.00 & 8.28 & 0.00 & 2.70 \\
Hairy disporum & 5.39 & 0.00 & 2.11 & 4.04 & 2.64 \\
Halberd-leaf violet & 3.89 & 1.52 & 3.73 & 0.00 & 2.49 \\
Lion's foot & 0.00 & 0.90 & 6.76 & 0.74 & 2.49 \\
Wild grape & 4.31 & 2.94 & 0.44 & 1.58 & 2.16 \\
Other herbaceous & & & & & \\
plants & 8.10 & 11.21 & 17.78 & 3.11 & 12.01 \\
Total & 300.00 & 300.00 & 300.00 & 300.00 & 300.00 \\
\hline
\end{tabular}

*Summation of the overall values above this line account for at least 75 percent of the importance of the list.

${ }^{\star \star}$ Treatments: $\mathrm{OT}=$ No thinning; $\mathrm{LT}=$ Low thinning; $\mathrm{HT}=$ High thinning and $S T=$ Selection thinning . 
Table 5

Treatment and overall importance values of woody species on mixed oak sites.

\begin{tabular}{|c|c|c|c|c|c|}
\hline \multirow[b]{2}{*}{ secies } & \multicolumn{4}{|c|}{ Treatment } & \multirow[b]{2}{*}{ Overall } \\
\hline & OT & LT & $\mathrm{HT}$ & ST & \\
\hline ted maple & 60.53 & 71.52 & 85.80 & 51.75 & 67.80 \\
\hline Back cherry & 74.48 & 54.45 & 77.39 & 49.44 & 63.25 \\
\hline Sessafras & 33.88 & 50.77 & 29.51 & 59.24 & 43.61 \\
\hline Back huckleberry & 9.81 & 22.80 & 10.09 & 42.01 & 21.92 \\
\hline Mestnut oak & 17.52 & 13.42 & 17.89 & 24.71 & 18.71 \\
\hline led oak & 17.01 & 10.80 & 9.15 & 7.62 & $11.24^{\star *}$ \\
\hline Haple-leaf viburnum & 25.03 & 11.64 & 5.31 & 0.43 & $\overline{10.12}$ \\
\hline Inite oak & 2.86 & 13.78 & 11.98 & 9.16 & 9.51 \\
\hline Alowering dogwood & 7.57 & 12.66 & 3.93 & 2.61 & 6.02 \\
\hline Sourwood & 7.66 & 0.56 & 9.16 & 4.39 & 5.51 \\
\hline 'raberry* & 0.00 & 1.90 & 0.00 & 15.30 & 4.66 \\
\hline Back oak & 4.83 & 1.71 & 5.74 & 5.69 & 4.62 \\
\hline jarlet oak & 2.56 & 11.72 & 3.74 & 0.93 & 4.47 \\
\hline 3ack gum & 7.17 & 3.06 & 2.23 & 5.08 & 4.16 \\
\hline Anxter flower & 2.03 & 7.41 & 6.55 & 0.78 & 4.10 \\
\hline rellow-poplar & 2.68 & 3.19 & 6.98 & 2.75 & 3.86 \\
\hline Aack birch & 6.48 & 1.04 & 3.29 & 4.74 & 3.81 \\
\hline wcumbertree & 6.71 & 1.04 & 3.15 & 2.79 & 3.48 \\
\hline Witch-hazel & 3.95 & 0.51 & 2.04 & 5.18 & 3.04 \\
\hline Mher woody plants & 7.24 & 6.02 & 6.07 & 5.40 & 6.11 \\
\hline Total & 300.00 & 300.00 & 300.00 & 300.00 & 300.00 \\
\hline
\end{tabular}

Significant differences between treatment values at the .10 level.

"Summation of the overall values above the line account for at least 75 percent of the importance of ne list.

\section{Discussion}

Quantitative Data. Total understory weight, number of herbaceous species, nd average woody height greater than $2 \mathrm{dm}$ variables on mixed oak sites were significantly affected by thinning method (Table 2). Total weight and average wight values were greatest on those plots receiving high thinning. Values for woth variables decreased from high to selection to low to no thinning reatments.

On mixed oak sites woody weights and total number of herbaceous species aso varied with the thinning treatment. High thinning again accounted for greater greenbrier weight and more herbaceous species in the understory. This thinning method also resulted in greater woody weights and greater werage woody stem heights than did other thinning regimes. Selection thinning, which also removed upper-crown-class trees, gave values greater than either low thinning or no thinning for these variables, with the exception of number of herbaceous species and total number of woody stems. 
Table 6

Treatment and overall importance values of herbaceous species on cove hardwood sites.

\begin{tabular}{lrrrrr}
\hline \hline & \multicolumn{5}{c}{ Treatment } \\
Species & \multicolumn{1}{c}{ OT } & \multicolumn{1}{c}{ LT } & \multicolumn{1}{c}{ HT } & \multicolumn{1}{c}{ ST } & Overall \\
\hline New York fern & 94.48 & 98.75 & 51.03 & 62.32 & 77.03 \\
Intermediate wood fern & 24.63 & 13.22 & 25.96 & 19.07 & 19.34 \\
Rubus spp. & 17.79 & 18.04 & 23.76 & 16.72 & 18.86 \\
Hairy disporum & 11.94 & 18.15 & 15.54 & 12.00 & 14.28 \\
Hay-scented fern & 1.46 & 10.67 & 30.93 & 12.34 & 13.98 \\
Common blue violet & 14.74 & 13.31 & 8.87 & 16.79 & 13.59 \\
Sweet white violet & 7.77 & 10.86 & 7.11 & 21.98 & 12.40 \\
Cinnamon fern & 10.94 & 9.00 & 2.78 & 23.18 & 12.12 \\
Wild yam & 9.80 & 14.18 & 10.46 & 7.83 & 10.42 \\
Indian cucumber-root & 14.37 & 11.20 & 8.16 & 7.46 & 10.22 \\
Roundleaf violet & 13.49 & 6.66 & 5.89 & 6.22 & 7.99 \\
Southern lady fern & 4.06 & 7.42 & 14.35 & 4.28 & $7.29 *$ \\
Blue wood aster & 4.89 & 6.28 & 10.42 & 6.33 & 6.87 \\
Whorled loosestrife & 1.67 & 7.29 & 13.92 & 4.59 & 6.78 \\
White snakeroot & 5.90 & 0.72 & 4.09 & 11.05 & 6.60 \\
Halberd-leaf violet & 6.39 & 7.45 & 5.84 & 3.06 & 5.48 \\
Jack-in-the-pulpit* & 2.95 & 1.66 & 2.51 & 13.22 & 5.46 \\
Wreath goldenrod & 4.55 & 5.20 & 6.12 & 2.25 & 4.41 \\
False nettle & 2.23 & 3.27 & 2.55 & 6.17 & 3.69 \\
Wild sarsaparilla & 4.69 & 4.45 & 2.98 & 2.33 & 3.56 \\
Christmas fern & 4.37 & 1.25 & 5.93 & 2.67 & 3.41 \\
Lion's foot & 3.05 & 2.68 & 2.16 & 1.86 & 2.42 \\
Panic grass & 2.84 & 2.42 & 2.42 & 1.72 & 2.34 \\
Other herbaceous & & & & & \\
$\quad$ plants & 15.25 & 16.91 & 24.81 & 20.52 & 20.74 \\
$\quad$ Total & 300.00 & 300.00 & 300.00 & 300.00 & 300.00 \\
\hline Siggifant & & & & &
\end{tabular}

*Significant differences between treatment values at the .10 level.

** Summation of the overall values above the line account for at least 75 percent of the importance of the list.

On oak sites those thinnings that involved removal of upper-crown-class trees apparently opened the crown enough to enable understory species to become established and persist. Increased light levels on the forest floor. resulted in greater woody and total weights along with higher average woody stem heights (Table 2). The effect of low thinning on the understory was not significant and differed little from the unthinned controls.

On cove sites (Table 3 ) improvement cuttings increased the number of herbaceous species. This suggests that some species persisted from the time of plot establishment when improvement operations took place. Both measures of woody stem heights showed greater average woody heights for plots that did not receive an improvement cutting. 
Table 7

Treatment and overall importance values of woody species on cove hardwood sites.

\begin{tabular}{lrrrrr}
\hline \hline & \multicolumn{5}{c}{ Treatment } \\
Species & \multicolumn{1}{c}{ OT } & \multicolumn{1}{c}{ LT } & \multicolumn{1}{c}{ HT } & \multicolumn{1}{c}{ ST } & Overall \\
\hline Black cherry & 94.93 & 66.34 & 63.10 & 56.22 & 69.82 \\
Red maple & 66.62 & 48.66 & 41.75 & 48.81 & 50.48 \\
Maple-leaf viburnum & 27.49 & 46.90 & 31.77 & 19.83 & 30.77 \\
Sassafras & 18.89 & 26.65 & 47.33 & 14.41 & 26.67 \\
Witch-hazel & 4.87 & 22.84 & 22.24 & 32.26 & 21.24 \\
Spicebush & 7.79 & 3.30 & 16.02 & 47.60 & 18.96 \\
Red oak & 17.33 & 12.93 & 11.97 & 23.99 & $17.38^{\star \star}$ \\
Yellow-poplar & 10.17 & 16.77 & 12.29 & 19.21 & 13.84 \\
Flowering dogwood & 27.08 & 12.34 & 4.81 & 3.20 & 12.03 \\
Black gum & 0.00 & 13.39 & 2.62 & 9.66 & 6.83 \\
Alternate-leaved & & & & & \\
$\quad$ dogwood & 10.06 & 5.52 & 6.53 & 3.26 & 6.19 \\
Black birch & 2.03 & 1.84 & 13.48 & 2.40 & 5.12 \\
Chestnut oak & 2.35 & 0.92 & 8.19 & 3.12 & 3.75 \\
Striped maple & 0.00 & 12.46 & 0.00 & 0.00 & 3.24 \\
Sourwood & 0.00 & 0.00 & 10.06 & 2.01 & 3.07 \\
White oak & 1.06 & 4.34 & 0.92 & 4.63 & 2.86 \\
Hawthorn & 2.03 & 0.00 & 1.72 & 3.02 & 2.04 \\
Other woody plants & 7.30 & 4.80 & 5.20 & 6.37 & 5.71 \\
$\quad$ Total & 300.00 & 300.00 & 300.00 & 300.00 & 300.00 \\
\hline
\end{tabular}

'Significant differences between treatment values at the 10 level.

"Summation of the overall values above the line account for at least 75 percent of the importance of the list.

For cove sites, selection thinning rather than high thinning resulted in greater understory weights, heights, and total number of species (Table 3). Trees cut from cove sites in selection thinnings were generally large-crowned yellow-poplars. Removing these super-dominants created large canopy openings which increased understory vigor, height, and species diversity. Plots receiving no thinning consistently accounted for the smallest values of understory measures. Low and high thinning plots ranked second or third depending on the variable concerned.

Qualitative Data. Compositional differences between herbaceous understories of mixed oak and cove hardwood sites are shown in Tables 4 and 6. Understory herbaceous communities on cove sites contained more species than those of oak sites. Cove understories were more complex and composed of many species of similar importance. New York fern ${ }^{1}$ was the most important species. On these sites inclusion of 13 species was necessary to account for 75 percent of the group's importance. However, on mixed oak sites 75 percent

Scientific names of trees, shrubs, and herbaceous vegetation are given in Appendix Table 1. 


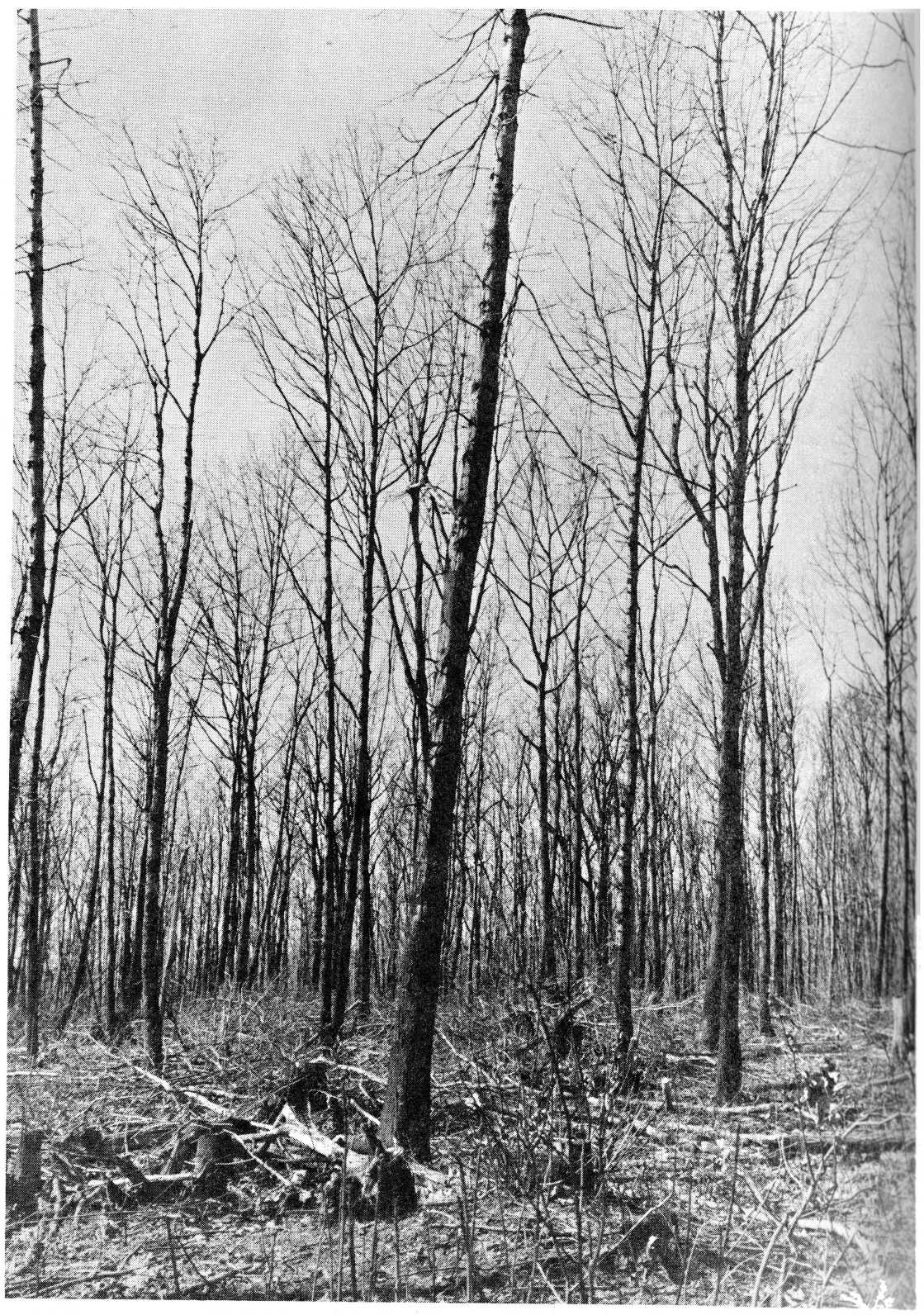

On mixed oak sites, those thinning methods which removed upper-crownclass trees, thus resulting in greater light reaching the forest floor, increased woody understory weight, total understory weight, and the average height of the woody understory. 
involved only seven understory herbaceous species. Common greenbrier, hay-scented fern, Rubus spp., wild yam, and Indian cucumber-root were species that expressed relatively high index values in both groups.

Compositional differences between the woody understories of mixed oak and cove hardwood sites are illustrated in Tables 5 and 7 . The major woody understory vegetation for both sites involves only six or seven species. Red naple and black cherry are the two most important species. Red maple was the most important on mixed oak sites and black cherry on cove hardwood sites. Sassafras and maple-leaf viburnum also expressed high index levels in both groups.

On cove hardwood sites sweet white violet and jack-in-the-pulpit were both of greater importance under selection thinning. Flowering dogwood, since it is more shade tolerant than many other cove understory species, had a greater mportance value on unthinned plots. Index values progressively decreased trom low to high to selection plots as more competitive species displaced lowering dogwood.

But in general few species were found to have significantly different index values under the various thinning regimes; those species that did were of esser importance. Thus, the importance of a given species relative to other species in that community was constant regardless of intermediate cutting received, and in this case thinning had little effect on the species composition of the understory.

\section{Conclusions}

The improvement cuttings received by half of the research plots were found to have little, if any, effect on the dependent variables tested for both mixed oak and cove hardwood sites.

Understory variables concerning total weights, number of herbaceous species, and average woody heights greater than $2 \mathrm{dm}$, were found to differ consistently with thinning treatment applied to mixed oak stands. In general the values of these variables decreased from high thinning to selection thinning plots to low thinning to plots which received no thinning.

Although none of the understory variables tested for cove hardwood sites snowed significant differences in all three analyses, the woody weight, total weight, total number of species, and average woody height differed significantly with thinning treatment for at least one of the analyses. Selection hinning rather than high thinning accounted for greater understory weights, neights, and number of species. Low thinning consistently accounted for the smallest values of these understory parameters.

Mixed oak site understory variables displayed a general tendency to ncrease with increases in site index and decreases in plot basal area. Greater understory weights and heights also occurred on cove hardwood sites as site ndex increased, but these increases were concentrated in fewer species and ewer woody stems.

Site index was found to be a more consistent and meaningful covariate than basal area. When basal area was tested as a dependent variable, no significant differences between thinning treatments were found. This suggested that either operations performed on these plots were too light or that values obtained from computing average residual basal area did not faithfully represent the degree of stand manipulation. 
Upon comparison of understory communities by means of synthetic index approach of importance values, it was found that many species occurred on both mixed oak and cove hardwood sites, even though their relative position varied. The majority of importance was concentrated in fewer herbaceous understory species for mixed oak sites than for cove hardwood sites. Few species were found to differ in their importance under the various thinning regimes. This indicated that the relative importance of a species to others in the community is constant regardless of the communal thinning response.

\section{Literature Cited}

Bennett, A. L. 1962. Industrial forestry and wildlife-the Northeast. J. Forest. 60:18-20.

Bower, D. R. and E. R. Ferguson. 1968. Understory removal improves shortleaf pine growth. J. Forest. 66:421-422.

Charlton, P. M., H. V. Wiant, Jr., and K. L. Carvell. 1980. Effects of intermediate cuttings in Appalachian hardwood stands. WV Forestry Notes 8.

Clark, F. B. and R. F. Watt. 1971. Silvicultural methods for regenerating oaks. In Oak Symposium Proc. USDA For. Serv. Northeast. For. Expt. Sta., Upper Darby, Pa. pp. 37-42.

Curtis, J. T. and R. P. Mclntosh. 1951. An upland forest continuum in the prairie-forest border region of Wisconsin. Ecology 32:476-496.

Grano, C. X. 1970. Small hardwoods reduce growth of pine overstory. USDA For. Serv. Expt. Sta. Res. Paper SO-55. 8 pp.

Knierim, P. G., K. L. Carvell, and J. D. Gill. 1971. Browse in thinned oak and cove hardwood stands. J. Wildl. Mgmt. 35:163-167.

Krefting, L. W. 1962. The use of silvicultural techniques for improving deer habitat in the Lake States. J. Forest. 60:40-42.

Leffelman, L. J. and R. C. Hawley. 1925. Studies of Connecticut hardwoods. Yale School of Forestry Bull. 15.

Sanders, I. L. 1972. Size of oak advance reproduction: key to growth following harvest cuttings. USDA For. Serv. Res. Paper NC-79. 6 pp.

Sharp, W. M. 1957. Management of a pole timber forest for wildlife food and cover. Penn. State Univ. Agr. Expt. Sta. Bull. 620. 12 pp.

Smith, R. L. 1974. Ecology and field biology (2nd ed.). Harper and Row Publishers, Inc., New York. 850 pp.

Steel, G. D. and J. H. Torrie. 1960. Principles and procedures of statistics. McGraw-Hill Book Co., Inc., New York. 471 pp.

Wiant, H. V., Jr. 1975. Schnur's site index curves for upland oaks formulated.J. Forest. 73:429.

Zahner, R. 1958. Hardwood understory depletes soil water in pine stands. For. Sci. 4:178-184. 
APPENDIX 


\section{Appendix Table 1}

Common and scientific names for trees, shrubs and woody vines, and herbaceous species.

\section{Common Names}

Trees

Birch, black

Cherry, black

Cucumbertree

Gum, black

Maple, red

Maple, striped

Oak, black

Oak, chestnut

Oak, northern red

Oak, scarlet

Oak, white

Sourwood

Yellow-poplar

Shrubs and Woody Vines

Dogwood, alternate-leaved

Dogwood, flowering

Grape, wild

Hawthorn

Huckleberry, black

Pinxter-flower

Spicebush

Teaberry

Viburnum, maple-leaf

Witch-hazel

Herbaceous Plants

Aster, blue wood

Bellwort, sessile-leaved

Bluegrass, annual

Brier, saw

Cucumber-root, Indian

Disporum, hairy

Fern, Christmas

Fern, cinnamon

Fern, hay-scented

Fern, intermediate wood

Fern, New York

Fern, southern lady

Goldenrod, wreath

\section{Scientific Names}

Betula lenta L.

Prunus serotina Ehrh.

Magnolia acuminata $\mathrm{L}$.

Nyssa sylvatica Marsh.

Acer rubrum L.

Acer pensylvanicum $\mathrm{L}$.

Quercus velutina Lam.

Quercus prinus L.

Quercus rubra L.

Quercus coccinea Muench.

Quercus alba L.

Oxydendrum arboreum (L.) DC.

Liriodendron tulipifera $\mathrm{L}$.

Cornus alternifolia L.f.

Cornus florida L.

Vitis spp. L.

Viburnum prunifolium L.

Gaylussacia baccata (Wang.) K. Koch

Rhododendron nudiflorum (L.) Torr.

Lindera benzoin (L.) Blume

Gaultheria procumbens L.

Viburnum acerifolium $\mathrm{L}$.

Hamamelis virginiana $\mathrm{L}$.

Aster cordifolius L.

Uvularia sessilifolia L.

Poa annua L.

Smilax glauca Walt.

Medeola virginiana $L$.

Disporum lanuginosum (michx.) Nichols.

Polystichum acrostichoides (Michx.)

Schott.

Osmunda cinnamomea L.

Dennstaedtia punctilobula (Michx.)

Moore

Dryopteris intermedia Gray

Thelypteris noveboracensis Nieuwl.

Athyrium asplenioides A. Eaton

Solidago caesia L. 


\section{Common Names}

'Herbaceous Plants

Grass, panic

ack-in-the-pulpit

Lon's-foot

.oosestrife, whorled

Nettle, false

Pipe, Indian

Rubus

Sarsaparilla, wild

Snakeroot, white

Solomon's-seal, common

Violet, common blue

violet, halberd-leaf

violet, roundleaf

Violet, sweet white

Yam, wild

\section{Scientific Names}

\author{
Panicum spp. L. \\ Arisaema triphyllum (L.) Schott \\ Prenanthes trifoliata (Cass.) Fernald \\ Lysimachia quadrifolia L. \\ Boehmeria cylindrica L. \\ Monotropa uniflora L. \\ Rubus spp. L. \\ Aralia nudicaulis L. \\ Eupatorium rugosum Houtt. \\ Polygonatum biflorum (Walt.) Ell. \\ Viola papilionacea Pursh \\ Viola hastata Michx. \\ Viola rotundifolia Michx. \\ Viola blanda Willd. \\ Dioscorea villosa L.
}




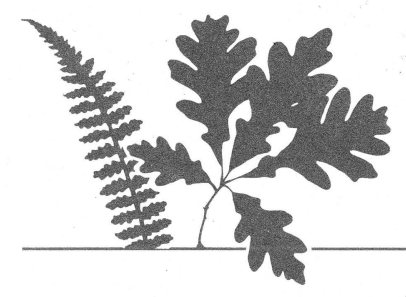

